\section{THE MUSK-OX.}

\section{T}

$\mathrm{E}$ Zoological Society of London being anxious to obtain living specimens of the musk-ox (Ovibos moschatus), well known as one of the characteristic inhabitants of Arctic regions, the Council of the Society have determined to offer the sum of five hundred pounds for five examples of this animal (two males and three females) delivered alive and in good condition in the Regent's Park Gardens, or a proportionate sum for a smaller number. It has been pointed out by $\mathrm{Col}$. Feilden, in an article upon "Animal Life in East Green. land," published in The Zoologist for Februaty last, that the southern range of the musk-ox, which was formerly supposed to be met with only in Arctic America, has now been satisfactorily shown to extend as far south on the east coast of Greenland as midway between the parallels of $70^{\circ}$ and $71^{\circ}$ N.L., and that it will in all probability be found in the future to extend along the coast line of Egede Land as far as the sixty-fifth parallel. Thus the abode of the musk-ox is brought comparatively close to Europe, and there seems to be no insuperable difficulty in procuring living specimens. Young muskoxen are very easily reared and tamed, and there could not be any very great difficulty in catching either old or young in Jameson's Land.

Although the more southern portion of the coast of East Greenland is shut off from access by an almost impenetrable ice barrier, it has been ascertained of late years that the more northern portion of this coast may

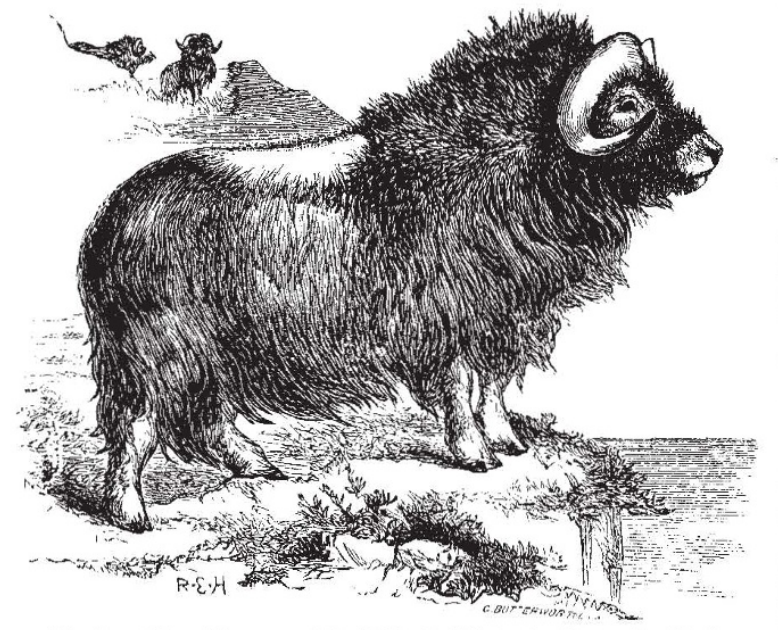

Musk-ox (from Flower and Lydekker"s "Introduction to the Study of Mammals," p. 358 ).

be reached with comparatively little difficulty. In I 889 Captain Knudsen, of the Norwegian sealer Hekla, landed on Clavering Island in $74^{\circ} 10^{\prime}$ N.L., and found musk-oxen in considerable numbers. Again, during the recent Danish East Greenland Expedition of $189 \mathrm{r}-92$, Lieut. Ryder managed to land on Jameson's Land in Scoresby's Sound, although the year was very unfavourable, and passed the winter there with great success, no sickness having occurred amongst the members of the expedition during all the time they were there.

Animal life, Lieut. Ryder tells us, is rich, especially in Jameson's Land, where reindeer are seen in wonderful numbers. Many musk-oxen were seen around Hurry's Inlet, and traces of foxes, hares, bears, ermines, and lemmings were observed in Jameson's Land. The richness of vegetation ( 150 flowering plants having been gathered in Scoresby's Sound) and the size attained by it, especially around the western basin, are most astonishing, especially in comparison with what is the case on the western coast of Greenland.
It is, therefore, evident that it is quite possible for the well-equipped Arctic navigator to land on this part of the east coast of Greenland in almost any ordinary year, and that he will find there an abundant supply of both animal and vegetable life. In the former category are the muskoxen, the young of which, as already stated, are easily captured and reared. When they are once placed on board ship there would appear to be no great difficulty in bringing them safe to England.

We subjoin the description of the musk-ox given in Flower and Lydekker's "Introduction to the Study of Mammals," the publishers of which (Messrs. Black) have kindly allowed us the use of the accompanying illustration.

The animal commonly known as the musk-ox (Ovibos moschatus), though approaching in size the smaller varieties of oxen, is in structure and habits closely allied to the sheep, its affinities being well expressed by the generic name Ovibos bestowed upon it by De Blainville. The specific name, as also the common English appellatives, "Musk-Ox," "Musk-Buffalo," or "Musk-Sheep," applied to it by various authors, refer to the musky odour which the animal exhales. This does not appear to be due to the secretion of a special gland, as in the case of the musk-deer; but it must be observed that, except as regards the osteology, very little is known of the anatomy of this species. It about equals in size the small Welsh and Scotch cattle. The head is large and broad. The horns in the old males bave extremely broad bases, meeting in the median line, and covering the brow and whole crown of the head. They are directed at first downwards by the side of the face, and then turn upwards and forwards, ending in the same plane as the eye. Their basal halves are of a dull white colour, oval in section and coarsely fibrous; their middle part smooth, shining, and round; their tips black. In the females and young males the horns are smaller, and their bases are separated from each other by a space in the middle of the forehead. The ears are small, erect, and pointed, and nearly concealed in the hair. The space between the nostrils and the upper lip is covered with close hair, as in sheep and goats, without any trace of the bare muffle of the oxen. The greater part of the animal is covered with long brown hair, thick, matted, and curly on the shoulders, so as to give the appearance of a hump, but elsewhere straight and hanging down; that of the sides, back, and haunches reaching as far as the middle of the legs and entirely concealing the very short tail. There is also a thick woolly underfur, shed in the summer. The hair on the lower jaw, throat, and chest, is long and straight, and hangs down like a beard or dewlap, though there is no loose fold of skin in this situation as in oxen. The limbs are stout and short, terminating in unsymmetrical hoofs, the external one being rounded, the internal pointed, and the sole partially covered with hair.

It is gregarious in habit, assembling in herds of twenty or thirty head, or, accorcling to Hearne, sometimes eighty or a hundred, in which there are seldom more than two or three full grown males. The musk-ox runs with considerable speed, notwithstanding the shortness of its legs. Major H. W. Feilden, Naturalist to the Arctic Expedition of 1875 , says :- "No person watching this animal in a state of nature could fail to see how essentially ovine are its actions. When alarmed they gather together like a flock of sheep herded by a collie dog, and the way in which they pack closely together and follow blindly the vacillating leadership of the old ram is unquestionably sheep-like. When thoroughly frightened they take to the hills, ascending precipitous slopes and scaling rocks with gre $t$ agility." They feed chiefly on grass, but also on moss, lichens, and tender shoots of the willow and pine. The female brings forth a single young one in the end of May or beginning of June, after a gestation of nine months. 